\title{
KRONIKA
}

DARIUSZ STĘPKOWSKI

Wydział Nauk Pedagogicznych

Uniwersytet Kardynała Stefana Wyszyńskiego

ORCID ID: http://orcid.org/oooo-0oo2-6855-1517
Forum Pedagogiczne

$9(2019) 2$, cz. 1

Wpłynęło: 28.05.2019

Zatwierdzono do druku: 26.06.2019

DOI: $10.21697 / \mathrm{fp} .2019 .2 .23$

\section{Sprawozdanie z V Ogólnopolskiej Konferencji Naukowej \\ z zakresu edukacji globalnej pt. „Edukacja globalna wobec wyzwań zrównoważonego rozwoju”, Warszawa, 23 maja 2019 roku}

Po raz piąty odbyła się na Wydziale Nauk Pedagogicznych (WNP) Uniwersytetu Kardynała Stefana Wyszyńskiego w Warszawie (UKSW) konferencja z zakresu edukacji globalnej. W tym roku jej tytuł brzmiał: „Edukacja globalna wobec wyzwań zrównoważonego rozwoju”. Patronat naukowy nad konferencją roztoczył Komitet Nauk Pedagogicznych, działający przy Polskiej Akademii Nauk. Na spotkanie w dniu 23 maja 2019 roku przybyło 24 prelegentów reprezentujących sześć ośrodków akademickich krajowych i trzy zagraniczne. Wśród występujących były również trzy osoby pochodzące z obszaru pozaakademickiego. Uczestnicy wygłosili 21 referatów, w tym pięć w języku angielskim.

Obrady podzielono na trzy części: dwie sesje plenarne i dwie równoległe grupy tematyczne. W imieniu organizatorów przybyłych powitał przewodniczący komitetu organizacyjnego - Zbigniew Babicki. Uroczystego otwarcie konferencji dokonał Witold Starnawski, prodziekan WNP UKSW. Witając gości, W. Starnawski podkreślił aktualność problematyki zrównoważonego rozwoju, a równocześnie zagrożenie ideologizacją. W imieniu gospodarzy prodziekan życzył wszystkim uczestnikom owocnych obrad.

W pierwszej sesji plenarnej obrady poprowadził Z. Babicki. Na początku przekazał on głos Anecie Rogalskiej-Marasińskiej z Uniwersytetu Łódzkiego. Prelegentka przedstawiła referat zatytułowany: Edukacja globalna a edukacja na rzecz zrównoważonego rozwoju - pożądana zmiana miejsc. A. Rogalska-Marasińska nakreśliła w nim kontekst problemów związanych $\mathbf{z}$ tematem konferencji. Ze szczególnym naciskiem wyeksponowała zależności łączące, jej zdaniem, edukację interkulturową, edukację globalną i edukację ekologiczną z dążeniami do zrównoważonego rozwoju. Jako druga została poproszona o zabranie głosu Ligia Tuszyńska, reprezentująca Akademię Pedagogiki Specjalnej im. M. Grzegorzewskiej w Warszawie. Temat jej wystąpienia brzmiał: Ślad ekologiczny wskaźnikiem poziomu edukacji dla zrównoważonego rozwoju. Mówczyni zapoznała zgromadzonych z koncepcją 
śladu ekologicznego (ang. ecological footprint) i jej zastosowaniem do oceny wpływu wywieranego przez cywilizację na środowisko naturalne. W Polsce ecological footprint tłumaczy się jako „ślad węglowy”. Na bazie tych rozważań L. Tuszyńska omówiła ideę kalkulatora śladu ekologicznego/węglowego i możliwość jej implementacji w edukacji. Z pomocą tego narzędzia można przykładowo w dość prosty sposób oszacować globalne konsekwencje indywidualnego stylu życia. Referentka podzieliła się osobistymi doświadczeniami z zakresu wykorzystania śladu ekologicznego/węglowego w edukacji ekologicznej i globalnej.

Kolejnymi mówczyniami były Eunika Baron-Polańczyk i Aneta Klementowska z Uniwersytetu Zielonogórskiego. Przedstawiły one temat Idee proekologiczne $w$ wytycznych programowych kształcenia ogólnego - ujęcie regionalne i lokalne.

Niekonwencjonalnie jak na konferencje naukowe na zakończenie pierwszej sesji plenarnej prowadzący zaprosił do przedstawienia referatu Wiesława Biernackiego, dyrektora pionu Strategii i Zarządzania Portfelem Projektów koncernu ORLEN. Tytuł referatu brzmiał: Rozwój branży E\&P $w$ aspekcie kształtowania i ochrony środowiska naturalnego na przykładzie działalności ORLEN Upstream. W. Biernacki skrótowo przedstawił wielopłaszczyznowe działania reprezentowanego przez siebie potentata naftowego w Polsce nie tylko na rzecz ochrony środowiska naturalnego, lecz także podnoszenia świadomości ekologicznej w społeczeństwie. Niektóre z tych działań zostały omówione bardziej szczegółowo.

Po ostatnim referacie moderator zaprosił do dyskusji, w której powrócono do kwestii zasygnalizowanych już w wystąpieniach, i je pogłębiono. Po dyskusji została ogłoszona przerwa.

Po przerwie uczestnicy konferencji spotkali się w dwu grupach tematycznych, które obradowały osobno. Moderatorem pierwszej był Dariusz Stępkowski. Zaprezentowano w niej siedem referatów, z których pięć zostało wygłoszonych w języku angielskim. Po każdym referacie była możliwość zadawania pytań i dyskutowania na temat poruszonych zagadnień.

Jako pierwszy zabrał głos Isaias Rivera, reprezentujący Corvinus University w Budapeszcie na Węgrzech. Tytuł jego referatu brzmiał: Globalization and Education: Comparative Education. Prelegent rozpoczął od podzielenia się ze słuchaczami swoimi osobistymi doświadczeniami odnośnie wielokulturowości. Na tej podstawie odniósł się do różnorodności językowej, która specyfikuje osoby - takie jak on - dużo podróżujące po świecie. Jego zdaniem sytuacja ta dobrze ilustruje problem, którym jest otwartość i gotowość do poznawania tego, co nowe i nieznane pomimo różnic i barier językowych.

Następnie została poproszona o zabranie głosu Anna Sádovská z Trnavská Univerzita w Trnawie na Słowacji, która przedstawiła referat zatytułowany: What do youth really care about? Interconnections of education for sustainable development and ethical education? Na początku prelegentka wyjaśniła, że jej zainteresowanie rozwojem zrównoważonym wynika z badań prowadzonych nad wychowaniem moralnym i kształceniem moralno-etycznym. Jej zdaniem na Słowacji brakuje 
refleksji teoretycznej nad edukacją ukierunkowaną na wartości w powiązaniu z kwestiami/problemami ekologicznymi. A. Sádovská omówiła swoje badania odnośnie postaw proekologicznych wśród młodzieży słowackiej w odniesieniu do takich wartości, jak altruizm, przyjaźń, życzliwość itp.

Kolejny referat w tej sesji wygłosiła Arleta Suwalska z Uniwersytetu Łódzkiego. Jego tytuł brzmiał: The direction of educational reforms and challenges for sustainable development in Finnish education. Referentka podzieliła się ze słuchaczami wynikami swoich badań dotyczących reform edukacyjnych w Finlandii. Reformy te doprowadziły do głębokiej zmiany nastawienia społecznego wobec ochrony przyrody i idei zrównoważonego rozwoju w ojczyźnie reniferów.

Czwarty referat został wygłoszony w duecie złożonym ze wspomnianego już Isaiasa Rivery i Barbart Głasek z Uniwersytetu Kardynała Stefana Wyszyńskiego w Warszawie. Wspólne wystąpienie zostało zatytułowane: Contemporary challenges of pre-school and early-school education in the context of the ongoing globalization process. Na początku referenci ponownie odwołali się do osobistych doświadczeń dotyczących omawianej problematyki. Na tej podstawie przedstawili współczesne wyzwania, jakie ich zdaniem wiążą się z implementacją idei zrównoważonego rozwoju w edukacji przedszkolnej i wczesnoszkolnej w Polsce.

Przechodząc do następnego punktu programu, moderator zaprosił do zabrania głosu Olgę Khyzhnę z Narodowego Uniwersytetu Pedagogicznego im. M.P. Dragomanowa w Kijowie (Ukraina). Tytuł wystąpienia gościa z Ukrainy brzmiał: Modernizacja przygotowania zawodowego przyszłych nauczycieli na Ukrainie: problemy, dylematy, kontrowersje. O. Khyzhna przedstawiła uczelnię, z której pochodzi. Na kanwie tego wskazała na kierunki zmian wprowadzanych w kształceniu akademickim na Ukrainie, w szczególności w zakresie studiów pedagogicznych. Zmiany te są ukierunkowane na tworzenie „nowej szkoły”. Zdaniem prelegentki idea ta nie jest doprecyzowana, co prowadzi do powierzchownych zmian w ukraińskim systemie edukacji wyższej, najczęściej o charakterze administracyjnym.

W kolejnym referacie Joanna Godawa z Uniwersytetu Śląskiego w Katowicach przedstawiła temat: Stan wiedzy studentów kierunków pedagogicznych na temat zrównoważonego rozwoju. Mówczyni w skrócie zrelacjonowała wyniki badania terenowego, które niedawno przeprowadziła. Jego przedmiotem było zjawisko, które określiła mianem „wykluczenia z natury”. Chodziło o ustalenie stopnia osobistego korzystania z kontaktu z przyrodą przez studentów pedagogiki specjalnej i nauczycieli przedszkola. Jak zauważyła mówczyni, analiza wyników wskazuje nie tylko na niesatysfakcjonujący poziom wiedzy pedagogów - zarówno tych już pracujących, jak i tych przygotowujących się jeszcze do pracy w oświacie - na tematy ekologiczne, lecz także na małe zaangażowanie osobiste na rzecz prowadzenia zdrowego trybu życia. Nie może więc dziwić, że problematyka zrównoważonego rozwoju wydaje się dość obca polskim edukatorom, przynajmniej na poziomie edukacji przedszkolnej i wszesnoszkolnej. 
Jako ostatnia w tej grupie wystąpiła Marta Gontarska, reprezentująca Towarzystwo Edukacji Antydyskryminacyjnej. Prelegentka swoim rozważaniom nadała tytuł: Cele zrównoważonego rozwoju wobec największych wyzwań globalnych - teoria i praktyka edukacyjna w Polsce i przedstawiła je w języku angielskim. M. Gontarska zwróciła uwagę, że w naszym kraju problematykę rozwoju zrównoważonego kojarzy się wciąż tylko z wychowaniem proekologicznym. Tymczasem rozszerzenie spektrum problemów wchodzących w zakres tego zagadnienia dokonało się w Europie w drugiej dekadzie XXI wieku w związku ze zjawiskiem masowej migracji. Obecnie, zdaniem prelegentki, do kwestii zrównoważonego rozwoju należą takie obszary pedagogiczne, jak edukacja międzykulturowa, edukacja globalna, edukacja emancypacyjna itp. Centralnym elementem tak szeroko rozumianego zrównoważonego rozwoju są, według M. Gontarskiej, wartości i przygotowanie do „światowego obywatelstwa” (ang. global citizenship).

W drugiej grupie tematycznej moderatorem był Witold Starnawski. Właśnie on wystąpił jako pierwszy prelegent. Przedstawił rozważania na temat: Edukacja globalna - kilka uwag terminologicznych. Po nim głos zabrała Katarzyna Stankiewicz z UKSW. Tytuł jest wystąpienia brzmiał: Międzykulturowe konteksty edukacji globalnej. Między teoria a praktyką. Referentka skierowała uwagę słuchaczy na wielo- i międzykulturowy charakter edukacji globalnej. W kolejnym wystąpieniu Agnieszka Klimska, również z UKSW, omówiła temat: Etyka w edukacji na rzecz zrównoważonego rozwoju $w$ warunkach ponowoczesności. Po niej prowadzący obrady poprosił o zabranie głosu Marcina Klimskiego z tego samego uniwersytetu co przedmówczyni. Filozof chrześcijański nadał swojemu referatowi tytuł: Edukacyjny wymiar inicjatyw społecznych na rzecz zrównoważonego rozwoju i zajął się w nim oddolnymi inicjatywami, które wspierają rozwijanie świadomości ekologicznej wśród dzieci i młodzieży. Również UKSW reprezentował Jan Niewęgłowski, który przedstawił temat: Troska o Ziemię. Ekologiczne wyzwania dla współczesnej pedagogiki. Jako następny wystąpił Tadeusz Piątek z Politechniki Rzeszowskiej. W referacie zatytułowanym Permakulturowy aspekt edukacji dla bezpieczeństwa wyjaśnił nowe zjawisko, z jakim mierzą się przedsiębiorcy z sektora gospodarczego. Mówiąc skrótowo, chodzi o to, żeby wytwarzanie różnego rodzaju dóbr materialnych planować jako samoregenerujący system, który oprócz produkcji będzie obejmował również ich utylizację. Potem głos zabrała Ariadna Ciążela z Akademii Pedagogiki Specjalnej im. M. Grzegorzewskiej w Warszawie. Tytuł jej wystąpienia brzmiał: Świadomość ekologiczna w programach kształcenia i sylwetka absolwenta a wiedza przyrodnicza studentów różnych kierunków studiów.

Na zakończenie obrad w drugiej grupie tematycznej Zbigniew Babicki z UKSW przedstawił referat pt. Edukacja dla zrównoważonego rozwoju a edukacja równoległa. Zdaniem mówcy edukacja dla zrównoważonego rozwoju przebiegała do tej pory w rożnych i nierodnych formach - zarówno w ramach kształcenia formalnego, jak i nieformalnego. Obecnie coraz większego znaczenia nabiera edukacja równoległa, 
którą będą urzeczywistniać już nie tylko instytucje oświatowe, lecz także grupy i organizacje społeczne oraz wspólnoty religijne.

Po zakończeniu obrad w obu grupach tematycznych ogłoszono przerwę na obiad.

Po przerwie uczestnicy konferencji zgromadzili się ponownie w głównym pomieszczeniu na drugiej sesji plenarnej. Posiedzenie rozpoczęło się od sprawozdań z obrad w grupach tematycznych, które przedstawili ich moderatorzy. Następnie prowadząca sesję Aleksandra Kulpa-Puczyńska przekazała głos Annie Florek, prezesce Fundacji „Czas Dzieciństwa” i dyrektorce przedszkola o tej samej nazwie. Referentka swoje wystąpienie opatrzyła tytułem: „Wszystkiego, co najważniejsze, nauczyłem się w przedszkolu”. Jak wychowywać i kształcić dla przyszłości? W jego trakcie A. Florek scharakteryzowała działalność wychowawczą i edukacyjną prowadzoną w założonym przez siebie przedszkolu integracyjnym.

Jako druga wystąpiła Anna Falkowska, doktorantka z Akademii Pedagogiki Specjalnej im. M. Grzegorzewskiej w Warszawie. Tytuł jej referatu brzmiał: Edukacja o bioróżnorodności w obliczu urbanizacji i konsumpcyjnego stylu życia.

Ostatnim akordem całodniowych obrad konferencyjnych było wystąpienie trójki studentów z WNP UKSW, którzy zaprezentowali projekt o nazwie The Unteachables. W jego realizację ze strony UKSW są zaangażowane dwa wydziały, a mianowicie Wydział Nauk Pedagogicznych i Wydział Biologii i Nauk o Środowisku. Projekt odbywa się w ramach międzynarodowego programu Erasmus+. Najpierw Marcin Bielecki przedstawił temat: Projekt Erasmus+ „The Unteachables” jako przykład zaangażowania studentów $w$ poszukiwanie rozwiązań globalnego problemu edukacyjnego. W trakcie swojego wystąpienia zrekapitulował powstanie grupy projektowej wśród studentów WNP i naszkicował ramy tematyczne projektu. Po nim Adrianna Wróbel i Aneta Żmijewska zaprezentowały wstępne wyniki badania przeprowadzonego wśród uczniów dwóch warszawskich liceów ogólnokształcących na temat wykorzystywania nowoczesnych technologii we własnym uczeniu się. Tytuł ich wystąpienia brzmiał: Oczekiwania nowego pokolenia uczniów wobec form i metod uczenia się - komunikat $z$ badań prowadzonych $w$ ramach projektu Erasmus+ „The Unteachables”.

Na zakończenie organizatorzy podziękowali uczestnikom za przybycie i zaprosili do spotkania się znowu za rok. 